\title{
Formation of gutingimycin: analytical investigation of trioxacarcin A-mediated alkylation of dsDNA
}

\author{
Ansgar Fitzner • Holm Frauendorf • Hartmut Laatsch • \\ Ulf Diederichsen
}

Received: 16 August 2007 / Revised: 29 October 2007 / Accepted: 5 November 2007 / Published online: 22 January 2008

(C) The Author(s) 2007

\begin{abstract}
Formation and fragmentation of recognition complexes between trioxacarcin A and various DNA sequences were examined by temperature-dependent $\mathrm{UV}$ and $\mathrm{CD}$ spectroscopy, HPLC analysis, and ESI mass spectrometry with regard to reaction conditions, intermediates, products, mechanism, and sequence specificity. Cleavage of the trioxacarcin-DNA complexes provided the natural product gutingimycin by guanine abstraction. The resulting DNA with an abasic site was further cleaved into a DNA fragment with a furanyl unit at the 3 '-end and an oligonucleotide with a phosphorylated $5^{\prime}$-end.
\end{abstract}

Keywords DNA alkylation · DNA strand cleavage ·

Electrospray mass spectrometry · Gutingimycin .

Trioxacarcin A

\section{Introduction}

Trioxacarcins are complex natural antitumor antibiotics with anti-malaria activity [1-3]. The first trioxacarcins were isolated from streptomycetes in 1981 by Tomita [1,2] and their structure was elucidated by Shirahata [4]. Gutingimycin (1) was isolated in 2004 from a marine streptomycete together with further trioxacarcin derivatives and named according to the ancient name of Göttingen $[3,5,6]$. It turned out to be an interesting natural product because of its mode

A. Fitzner $\cdot$ H. Frauendorf $\cdot H$. Laatsch $\cdot$ U. Diederichsen $(\bowtie)$ Institut für Organische und Biomolekulare Chemie,

Georg-August-Universität Göttingen,

Tammannstr. 2,

37077 Göttingen, Germany

e-mail: udieder@gwdg.de of formation. The structure of gutingimycin (1), elucidated by X-ray analysis, suggested that gutingimycin (1) results from nucleophilic attack of the N7 atom of a guanine subunit in DNA at the epoxide of trioxacarin A (2) [5]. Natural antibiotics like hedamycin and altromycin $\mathrm{B}$ are able to intercalate into the dsDNA followed by alkylation of guanine at the N7 position because of their epoxide functionality [7-9]. Like hedamycin, altromycin B or kapurimycin A3 [10, 11], trioxacarcin A (2) contains an epoxide. Therefore, it has been proposed that gutingimycin (1) is not built up from low-molecular-weight precursors [5]. As for other cytotoxic natural products, it is likely that alkylation of trioxacarin A (2) is followed by depurination and DNA strand scission at the abasic site [7, 12-14]. Saito obtained derivatives structurally related to gutingimycin (1) by reaction of kapurimycin $\mathrm{A} 3$ with various oligonucleotides. At $0{ }^{\circ} \mathrm{C}$ a stable ionic intermediate is formed; on heating to $90^{\circ} \mathrm{C}$ this dissociates into a depurinated oligonucleotide and a kapurimycin derivative $[15,16]$. Hedamycin binds to dsDNA by intercalation and alkylation with a distinct preference for the central guanine in the sequence $\mathrm{d}(\mathrm{CGT})$ or $\mathrm{d}(\mathrm{CGG})[8,17$, 18]. The covalent hedamycin-DNA adduct was isolated by Sheil and characterized by ESI MS [19, 20].

From previous studies it was known, that trioxacarcin A (2) also forms a stable complex with dsDNA, but did not react with deoxyguanosine even at higher temperatures [1]. The aim of this study was to investigate the conditions and mechanism of the trioxacarcin-mediated alkylation of dsDNA by applying high-performance liquid chromatography and highresolution electrospray mass spectrometry together with temperature-dependent UV and CD spectroscopy. In particular, the influence of the DNA sequence on binding and adduct formation and the identification of intermediates and cleavage products like gutingimycin (1) and DNA fragments is described in detail. 
Fig. 1 Gutingimycin (1), trioxacarcin $\mathrm{A}(\mathbf{2})$, and trioxacarcin B (3)

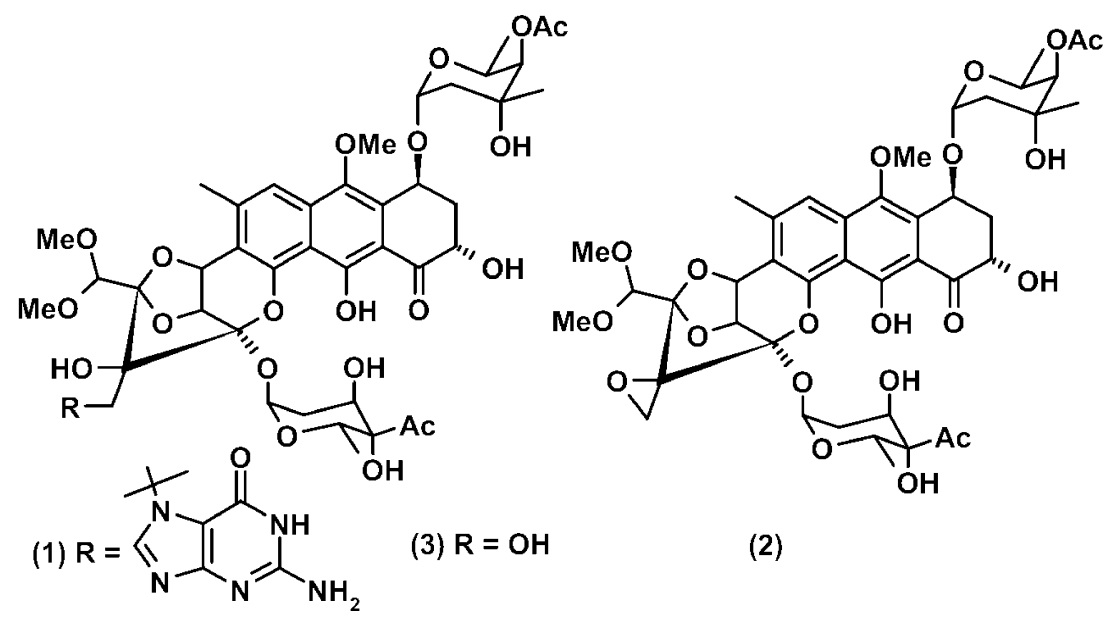

\section{Experimental}

Methods and materials

The DNA oligomers d(AATTACGTAATT) (4a), d(CAATTA TAATTG) (4b), d(AATTXGXAATT) (5a-d), and the complementary oligonucleotides d(AATTGGGAATT) (7) and d (TTAACCCTTAA) (8) were purchased from IBA (Göttingen, Germany). An oligomer length of eleven or twelve nucleotides was sufficient to provide stability at room temperature $\left(T_{\mathrm{m}}=22-35{ }^{\circ} \mathrm{C}\right)$. Trioxacarcin A (2) and trioxacarcin B (3) were obtained by fermentation of Streptomyces sp. isolate B8652 [6]. The reactions were carried out in aqueous phosphate buffer $\left(10 \mathrm{mmol} \mathrm{L}{ }^{-1} \mathrm{Na}_{2} \mathrm{HPO}_{4} / \mathrm{NaH}_{2} \mathrm{PO}_{4}, 0.1 \mathrm{~mol} \mathrm{~L}^{-1}\right.$ $\mathrm{NaCl}, \mathrm{H}_{2} \mathrm{O}, \mathrm{pH} 7.0$ ) with $5 \mu \mathrm{mol} \mathrm{L}{ }^{-1}$ dsDNA and trioxacarcin $\mathrm{A}(2)$ in a 1:2 ratio.

\section{UV spectroscopy}

Melting curves were measured on a Perkin-Elmer Lambda 10 UV-visible spectrophotometer in connection with a
Perkin-Elmer PTP-1 Peltier system following the temperature program: $0{ }^{\circ} \mathrm{C}(15 \mathrm{~min}) \rightarrow 90{ }^{\circ} \mathrm{C}(180 \mathrm{~min}) \rightarrow 0{ }^{\circ} \mathrm{C}$ (180 min). dsDNA ( $30 \mathrm{nmol})$ was dissolved in $1.5 \mathrm{~mL}$ phosphate buffer $\left(10 \mathrm{mmol} \mathrm{L} \mathrm{Na}_{2} \mathrm{HPO}_{4} / \mathrm{NaH}_{2} \mathrm{PO}_{4}, 0.1 \mathrm{~mol} \mathrm{~L}\right.$ $\left.\mathrm{NaCl}, \mathrm{H}_{2} \mathrm{O}, \mathrm{pH} 7.0\right)$, trioxacarcin $\mathrm{A}(2)(60 \mathrm{nmol})$ in $1.5 \mathrm{~mL}$ phosphate buffer was added and the measurement was performed at a wavelength of $\lambda=260 \mathrm{~nm}$ in a quartz cuvette $(1 \mathrm{~cm})$.

\section{CD spectroscopy}

CD spectra were obtained on a Jasco J-810 spectropolarimeter at room temperature (data mode: $\mathrm{CD}$, band width $1.0 \mathrm{~nm}$, slit width: auto, sensitivity: $5 \mathrm{mdeg}$, time const.: $4.0 \mathrm{~s}$; step

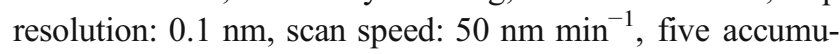
lations). dsDNA ( $30 \mathrm{nmol}$ ) was dissolved in $1.5 \mathrm{~mL}$ phosphate buffer $\left(10 \mathrm{mmol} \mathrm{L}^{-1} \mathrm{Na}_{2} \mathrm{HPO}_{4} / \mathrm{NaH}_{2} \mathrm{PO}_{4}, 0.1 \mathrm{~mol} \mathrm{~L}{ }^{-1}\right.$ $\left.\mathrm{NaCl}, \mathrm{H}_{2} \mathrm{O}, \mathrm{pH} 7.0\right)$, trioxacarcin A (2) $(60 \mathrm{nmol})$ in $1.5 \mathrm{~mL}$ phosphate buffer was added and the measurement was performed in a quartz cuvette $(1 \mathrm{~cm})$.
Fig. 2 UV-melting curve of d(AATTACGTAATT) (4a) with and without trioxacarcin A (2) $\left(5 \mu \mathrm{mol} \mathrm{L}{ }^{-1}, 1: 2\right)$

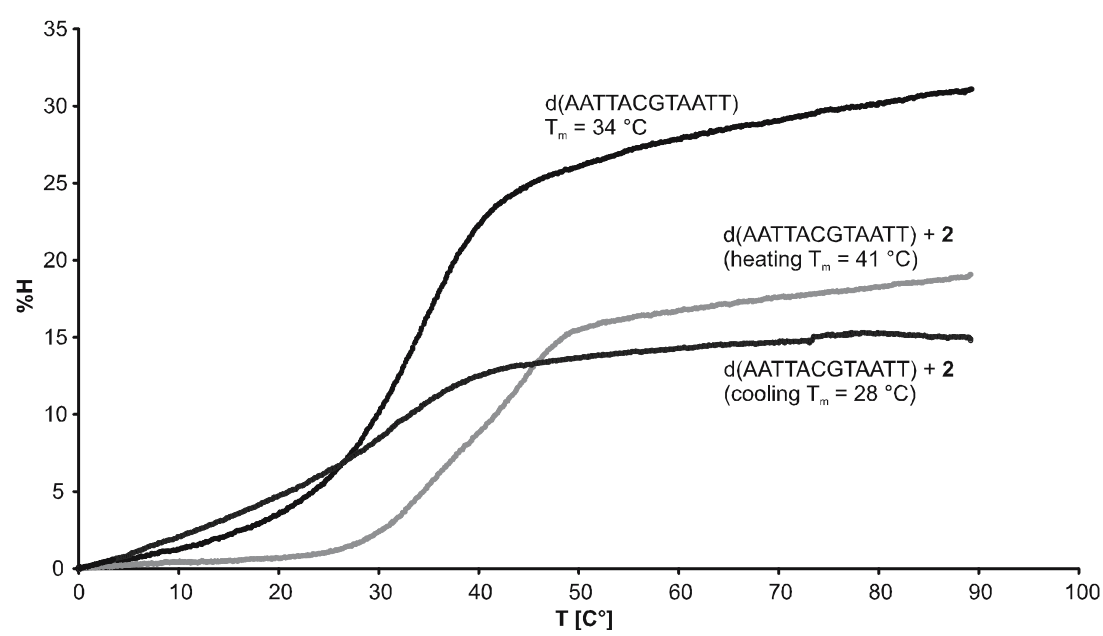


Fig. 3 UV-melting curve of d(CAATTATAATTG) (4b) with and without trioxacarcin A (2) $\left(5 \mu \mathrm{mol} \mathrm{L}{ }^{-1}, 1: 2\right)$

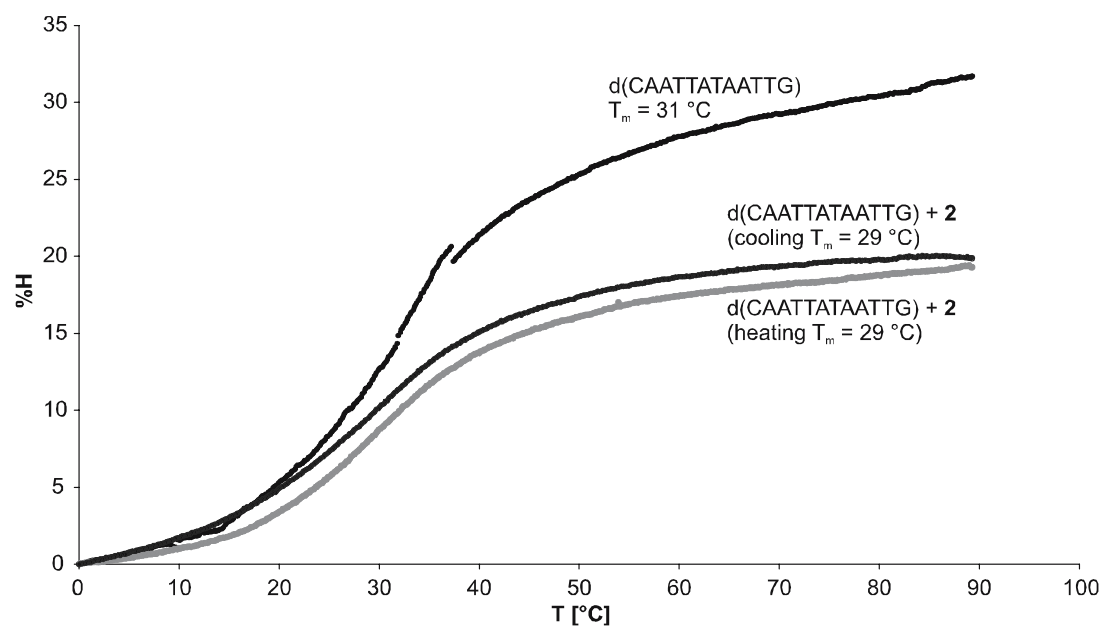

Kinetic measurements

A solution of trioxacarcin-DNA (30 nmol) adduct in phosphate buffer $\left(600 \mu \mathrm{L}, 10 \mathrm{mmol} \mathrm{L}{ }^{-1} \mathrm{Na}_{2} \mathrm{HPO}_{4} / \mathrm{NaH}_{2} \mathrm{PO}_{4}\right.$, $0.1 \mathrm{~mol} \mathrm{~L}^{-1} \mathrm{NaCl}, \mathrm{H}_{2} \mathrm{O}, \mathrm{pH} 7.0$ ) was heated to $80^{\circ} \mathrm{C}$ for $4 \mathrm{~h}$. Samples of $60 \mu \mathrm{L}$ were taken after $0,15,30,45,60,75,90$, 120, and $240 \mathrm{~min}$ and analyzed by HPLC. The area under the curve of the trioxacarcin-DNA adduct peak was plotted versus time to determine the time constant as the slope of the regression line.

\section{High-performance liquid chromatography}

HPLC separations were performed with an Äkta purifier from Amersham Pharmacia Biotech, a UV900 UV detector operated at $260 \mathrm{~nm}$, a NewGuard RP-8 Brownlee Precolumn $(15 \times 3.2 \mathrm{~mm}, 7 \mu \mathrm{m})$, and an Aquapore RP-300 Brownlee Column $(220 \times 4.6 \mathrm{~mm}, 7 \mu \mathrm{m})$ from Perkin-Elmer. Samples were eluted within $45 \mathrm{~min}$ with a flow rate of $1 \mathrm{~mL} \mathrm{~min}^{-1}$ by applying a two-stage gradient $(5-20 \% \mathrm{~B}$ in $20 \mathrm{~min}$ and 20 $45 \% \mathrm{~B}$ in $25 \mathrm{~min}$ ). Eluent A: $0.1 \mathrm{~mol} \mathrm{~L}^{-1}$ triethylammonium acetate buffer $\left(\mathrm{H}_{2} \mathrm{O}, \mathrm{pH}\right.$ 7.0). Eluent $\mathrm{B}: 0.1 \mathrm{~mol} \mathrm{~L}^{-1}$ triethylammonium acetate buffer $(80 \%$ acetonitrile and $20 \%$ water, $\mathrm{pH}$ 7.0).

\section{Electrospray mass spectrometry}

To a solution of $120 \mathrm{nmol}$ dsDNA in phosphate buffer $\left(10 \mathrm{mmol} \mathrm{L}^{-1} \mathrm{Na}_{2} \mathrm{HPO}_{4} / \mathrm{NaH}_{2} \mathrm{PO}_{4}, 0.1 \mathrm{~mol} \mathrm{~L}^{-1} \mathrm{NaCl}, \mathrm{H}_{2} \mathrm{O}\right.$, $\mathrm{pH}$ 7.0) a fivefold excess of trioxacarcin A (2) was added. The resulting mixture was incubated several hours at $0{ }^{\circ} \mathrm{C}$ and the trioxacarcin-DNA adduct formed was isolated by HPLC. High-resolution mass spectrometry was performed using an Apex IV 7 T FTICR MS (Bruker Daltonics, Billerica, MA, USA) equipped with an Apollo electrospray ion source which was used in the negative ion mode (capillary voltage $4.2 \mathrm{kV}$, end plate voltage $3.8 \mathrm{kV}$ ). Analytes were dissolved in a water-methanol (50:50) solution and introduced by a syringe pump at a flow rate of $2 \mu \mathrm{L} \min ^{-1}$. Nitrogen was used as drying gas at $100{ }^{\circ} \mathrm{C}$. Hexapole accumulation was set between $0.2 \mathrm{~s}$ to $3.0 \mathrm{~s}$ and mass spectra were acquired within the mass range $m / z 400$ to 2000 with a resolution of about 100,000 at $\mathrm{m} / \mathrm{z} 600$. The capillary exit voltage was $-80 \mathrm{~V},-100 \mathrm{~V},-140 \mathrm{~V}$, or $-170 \mathrm{~V}$. Deconvolution and mass calculation for the corresponding ions were done using Xmass 6.1.2 from Bruker.

\section{Results and discussion}

In order to investigate the sequence dependency of guanine abstraction from dsDNA by trioxacarcin A (2), the two self complementary DNA oligomers d(AATTACGTAATT) (4a) and d(CAATTATAATTG) (4b) were investigated with the reactive guanine located in the center or at the end of the double strand. The position of guanine was varied to de-

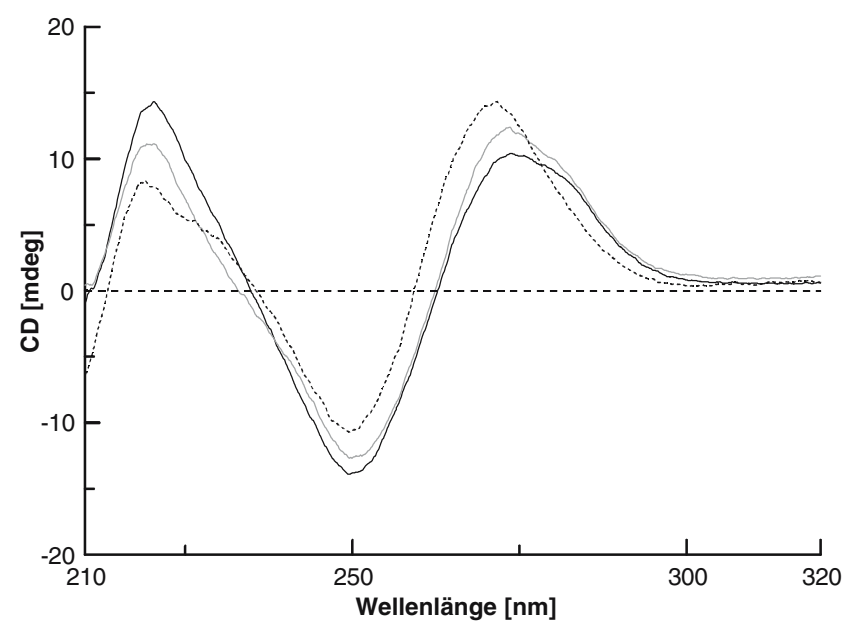

Fig. 4 CD-spectra of self pairing d(AATTACGTAATT) (4a) with (grey) and without (black) trioxacarcin A (2) $\left(5 \mu \mathrm{mol} \mathrm{L} \mathrm{L}^{-1}, 1: 2\right)$. The dashed line indicates the spectrum obtained after interim heating to $90{ }^{\circ} \mathrm{C}$ 
a

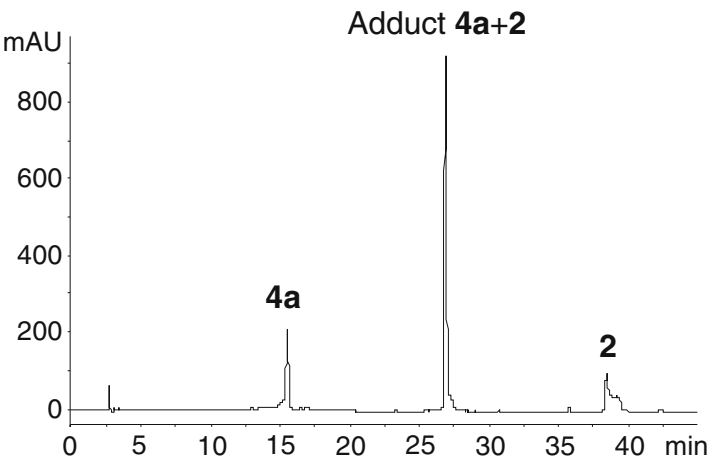

b

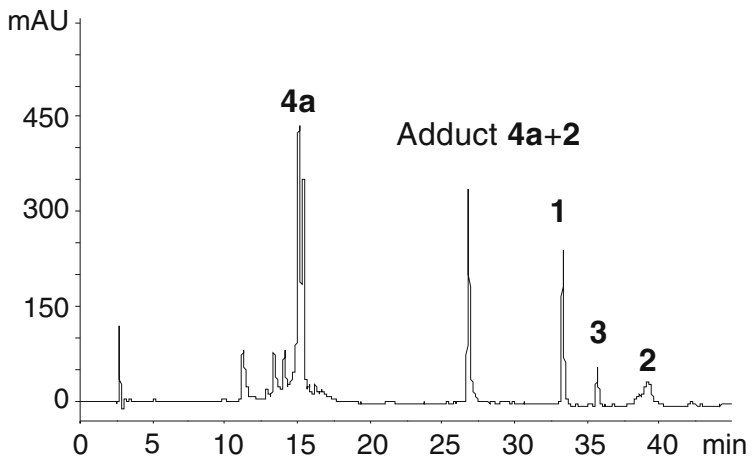

Fig. 5 HPLC chromatogram of a mixture of oligonucleotide $4 \mathbf{a}$ and trioxacarcin A (2): $\mathbf{a}$ at room temperature; $\mathbf{b}$ after heating to $90{ }^{\circ} \mathrm{C}$; next to DNA 4a further oligonucleotides and oligonucleotide fragments are eluting between 11 and $17 \mathrm{~min}$

termine the influence of the helix topology on alkylation. Four additional non-self complementary oligonucleotides with the general sequence d(AATTXGXAATT) (5a-d) together with the corresponding complementary strands were examined with respect to sequence specificity. The sequences were limited to only one guanine in the double strand in order to limit alkylation to a single site. It was placed in the central position investigating all possible alterations of the neighboring nucleobases using adenine and thymine.

A first approximation of the interaction of trioxacarcin A (2) with double-stranded DNA can be obtained from temperature dependent UV-spectroscopic measurements of double-strand stabilities, because double-strand recognition, formation of a covalent adduct, nucleobase excision, or strand scission are expected to affect DNA stability. A mixture of double-stranded oligonucleotide d(AATTACGTAATT) (4a) with two equivalents trioxacarcin A (2) gave a stability of $T_{\mathrm{m}}=41{ }^{\circ} \mathrm{C}$ which is significantly higher than the double strand transition of oligomer $4 \mathbf{a}$ without addition of the natural product $\left(T_{\mathrm{m}}=34{ }^{\circ} \mathrm{C}\right)$ (Fig. 2) indicating a DNA interaction with the trioxacarcin A (2). For this interaction intercalation and groove binding of the aglycon is more likely than covalent linkage of $\mathbf{2}$, because double-strand stability obtained for d(AATTACGTAATT) (4a) with trioxacarcin B (3) is similarly increased $\left(T_{\mathrm{m}}=42{ }^{\circ} \mathrm{C}\right)$ even though trioxacarcin B (3) is not able to alkylate DNA. In the cooling cycle the UV melting curve of the $\mathbf{4 a} / \mathbf{2}$ mixture provided only a stability of $T_{\mathrm{m}}=28{ }^{\circ} \mathrm{C}$. This destabilization is most likely because of nucleobase excision initiated at higher temperatures to yield gutingimycin (1) and a DNA double strand with apurine site which might further lead to DNA strand scission.

In contrast, for the oligomer with the terminal guanine $\mathbf{4 b}$ the differences in double-strand stability were not significant comparing the self pairing $\left(T_{\mathrm{m}}=31^{\circ} \mathrm{C}\right)$ with the $1: 2$ mixture of oligomer $\mathbf{4 b}$ and natural product $\mathbf{2}$ in the heating $\left(T_{\mathrm{m}}=29^{\circ} \mathrm{C}\right)$ or cooling cycle $\left(T_{\mathrm{m}}=29^{\circ} \mathrm{C}\right)$ (Fig. 3). Apparently, for DNA recognition of trioxacarcin A (2) the double helix topology is required which is not sufficiently assured at the terminus of the helix. Therefore, the guanine placed at the terminal position cannot act as a nucleophile without the help of helix recognition. This is in agreement with guanosine itself not being a nucleophile for trioxacarcin A (2) [1].
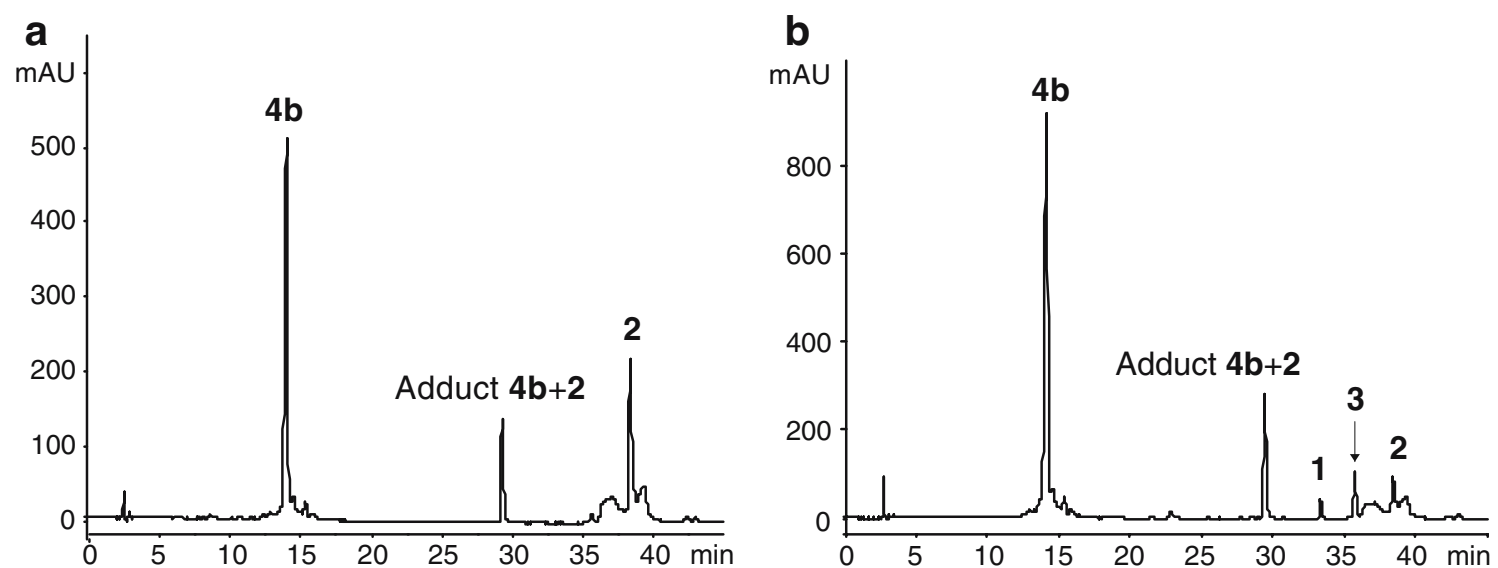

Fig. 6 HPLC chromatogram of a mixture of the oligonucleotide $4 \mathbf{b}$ and trioxacarcin A (2): a at room temperature; $\mathbf{b}$ after heating to $90{ }^{\circ} \mathrm{C}$ 
Table 1 Examined oligomers and adduct formation

\begin{tabular}{llllll}
\hline DNA oligomers & & Adduct formula & $\begin{array}{l}{\left[\mathrm{M}_{\text {adduct }}-6 \mathrm{H}\right]^{6-\text { a calcd. } /}} \\
\text { found mass }\end{array}$ & $\begin{array}{l}{\left[_{\text {adduct }}+\mathrm{Na}-7 \mathrm{H}\right]^{6-\text { a }} \text { calcd. / }} \\
\text { found mass }\end{array}$ \\
\hline AATTACGTAATT & $\mathbf{4 a}$ & $\mathrm{C}_{161} \mathrm{H}_{202} \mathrm{~N}_{43} \mathrm{O}_{90} \mathrm{P}_{11}$ & $752.32 / 752.33$ & $755.99 / 755.99$ & 53 \\
CAATTATAATTG & $\mathbf{4 b}$ & $\mathrm{C}_{161} \mathrm{H}_{202} \mathrm{~N}_{43} \mathrm{O}_{90} \mathrm{P}_{11}$ & $752.32 / 752.39$ & $755.99 / 756.00$ & 10 \\
AATTAGTAATT & $\mathbf{5 a}$ & $\mathrm{C}_{152} \mathrm{H}_{190} \mathrm{~N}_{40} \mathrm{O}_{84} \mathrm{P}_{10}$ & $704.15 / 704.16$ & $707.81 / 707.83$ & 13 \\
AATTTGAAATT & $\mathbf{5 b}$ & $\mathrm{C}_{152} \mathrm{H}_{190} \mathrm{~N}_{40} \mathrm{O}_{84} \mathrm{P}_{10}$ & $704.15 / 704.16$ & $707.81 / 707.82$ & 5 \\
AATTTGTAATT & $\mathbf{5 c}$ & $\mathrm{C}_{152} \mathrm{H}_{191} \mathrm{~N}_{37} \mathrm{O}_{86} \mathrm{P}_{10}$ & $702.65 / 702.65$ & $706.31 / 706.31$ & 16 \\
AATTAGAAATT & $\mathbf{5 d}$ & $\mathrm{C}_{152} \mathrm{H}_{189} \mathrm{~N}_{43} \mathrm{O}_{82} \mathrm{P}_{10}$ & $705.65 / 705.66$ & $709.31 / 709.32$ & 1 \\
\hline
\end{tabular}

a Adduct ions up to the sevenfold charged ion were observed; the relative intensities varied from oligomer to oligomer

${ }^{\mathrm{b}}$ Conversion rate given by the trioxacarcin $\mathrm{A}$ to adduct proportion

The modification of DNA 4a by trioxacarcin A (2) was also indicated by CD spectroscopy (Fig. 4). The spectra of 4a and the mixture of $\mathbf{4 a}$ with $\mathbf{2}$ measured at room temperature are quite similar, whereas the $\mathrm{CD}$ spectrum of the 4a/2 mixture heated to $90{ }^{\circ} \mathrm{C}$ differed by a shift and the intensity of the Cotton effect around 270, 250, and $220 \mathrm{~nm}$.

For a more detailed picture of trioxacarcin A (2) adduct formation with dsDNA, high-performance liquid chromatography was applied determining the components present after mixing at room temperature and after heating to $90{ }^{\circ} \mathrm{C}$. The HPLC chromatogram of the mixture of oligonucleotide 4a with trioxacarcin A (2) before starting the heating cycle provided three peaks (Fig. 5a). Next to DNA (4a) and trioxacarcin A (2), an additional compound was indicated which was assigned to the stable covalent complex between the oligonucleotide and the natural product trioxacarcin A $(\mathbf{4 a}+\mathbf{2})$. The compound corresponding to peak $(\mathbf{4 a}+\mathbf{2})$ was isolated and characterized by high-resolution ESI MS as the DNA-trioxacarcin A adduct. After heating to $90{ }^{\circ} \mathrm{C}$ additional peaks appeared in the oligonucleotide area together with gutingimycin (1) and trioxacarcin B (3) generated by epoxide ring opening of trioxacarcin A (2) with water (Fig. 5b). The assignment of all HPLC peaks was confirmed by co-injection and mass spectrometry.

Examining the trioxacarcin A (2) interaction with oligomer d(CAATTATAATTG) (4b) carrying the guanine at the terminal position, the HPLC chromatogram turned out to be quite similar to the HPLC chromatogram obtained after interaction with DNA 4a. Nevertheless, the yield of the respective DNA-trioxacarcin adduct $(\mathbf{4 b}+\mathbf{2})$ was significantly lower and gutingimycin (1) was only obtained in traces after heating (Fig. 6). As indicated in Table 1, adduct formation of trioxacarcin A (2) with oligonucleotide 4a is about five times more efficient than binding to DNA 4b. Sterically, the nucleophilic attack should be easier at the end of the double helix, but the ease of adduct formation turned out to be higher in the central position of the double strand. Therefore, trioxacarcin A (2) seems to take advantage of dsDNA recognition by intercalation or groove binding prior to nucleophilic attack. This recognition behavior is also described for the natural products hedamycin and altromycin B of the pluramycin family [7, 8, 21, 22].

The isolated adduct of oligonucleotide $\mathbf{4 a}$ with trioxacarcin A (2) is stable at room temperature for more than $24 \mathrm{~h}$ and at $56{ }^{\circ} \mathrm{C}$ for at least $4 \mathrm{~h}$. At $80{ }^{\circ} \mathrm{C}$ within $4 \mathrm{~h}$, decay to gutingimycin (1) was observed obeying first-order kinetics (Fig. 7).

In order to get preliminary information about sequence selectivity in trioxacarcin A (2) recognition and alkylation, all adenine and thymine combinations were investigated as the neighboring nucleobases of a central guanine. The four oligonucleotides 5a-d reacted with trioxacarcin A (2) to yield the corresponding adducts, which were characterized by high-resolution ESI MS. The corresponding HPLC profiles of oligomers $\mathbf{5 a}-\mathbf{d}$ with trioxacarcin A (2) before and after heating to $90{ }^{\circ} \mathrm{C}$ were almost similar, except for the peak height of the generated adducts. The conversion rate was calculated from the peak area proportion of trioxacarcin A (2) to the adduct. As indicated in Table 1, the conversion rate from trioxacarcin A (2) to the corresponding DNA adducts varied from 1 to $16 \%$. Based on non-self complementary double strands $\mathbf{5 a}-\mathbf{d}$ and results obtained by HPLC and ESI MS, adduct formation seems to be preferred when thymine is placed next to guanine with thymine neighboring the 3 '-site having a greater impact. It still needs to be investigated if this result holds only for thymine in comparison with

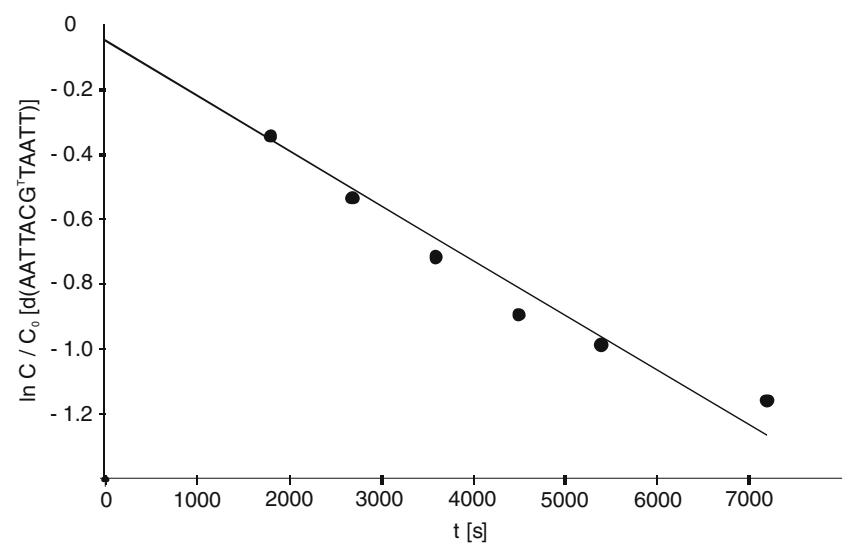

Fig. 7 Kinetic analysis based on a decay of the d(AATTACG TAATT)-trioxacarcin A adduct $(\mathbf{4 a}+\mathbf{2})[23]$ 

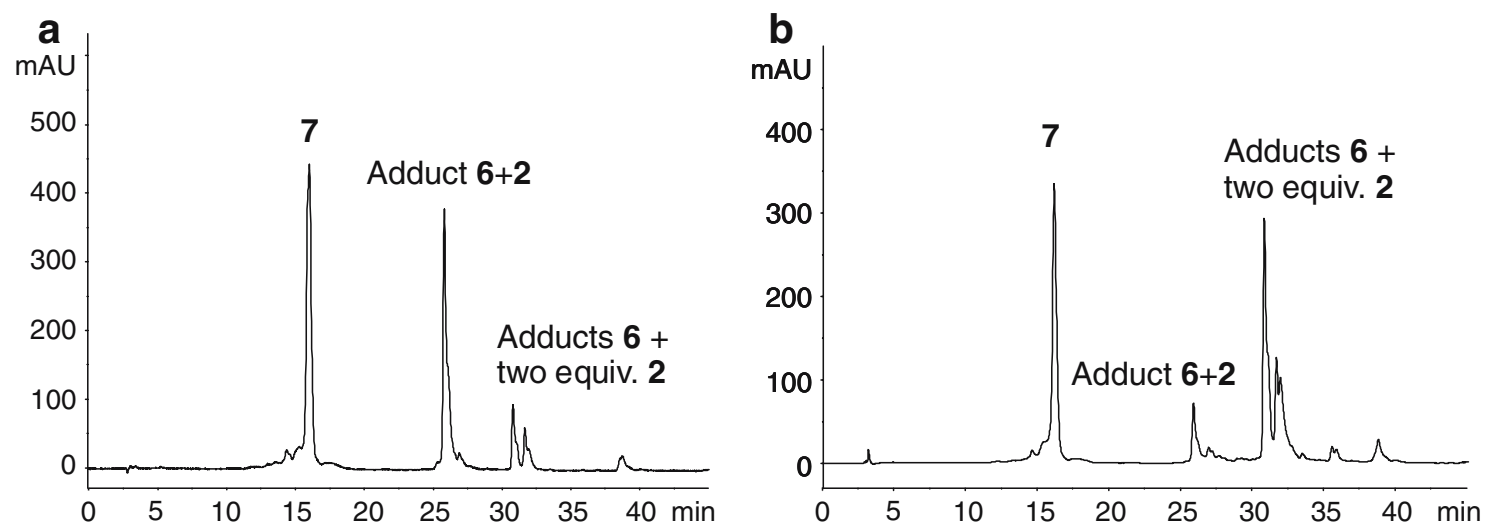

Fig. 8 HPLC chromatograms of a mixture of the DNA double strand d(AATTGGGAATT) (6) + d(TTAACCCTTAA) (7) and trioxacarcin A (2): a $24 \mathrm{~h}$ at $0{ }^{\circ} \mathrm{C}$ and $\mathbf{b} 72 \mathrm{~h}$ at $0{ }^{\circ} \mathrm{C}$

adenine or if this is a more general preference for pyrimidines over purines neighboring the trioxacarcin-substituted guanine.

The alkylation of oligomers with more than one guanine was investigated with the double strand formed by the complemen- tary strands d(AATTGGGAATT) (6) and d(TTAACCCTTAA) (7) which provide a quite stable double strand $\left(T_{\mathrm{m}}=35^{\circ} \mathrm{C}\right)$. In a mixture of $6+7$ with six equivalents of trioxacarcin A (2) the double strand stability decreased to $T_{\mathrm{m}}=29^{\circ} \mathrm{C}$ (heating

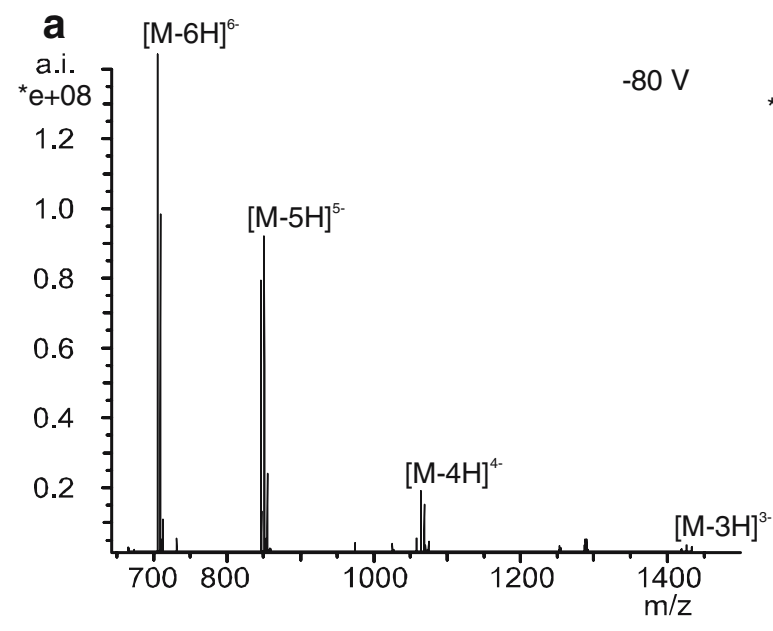

b
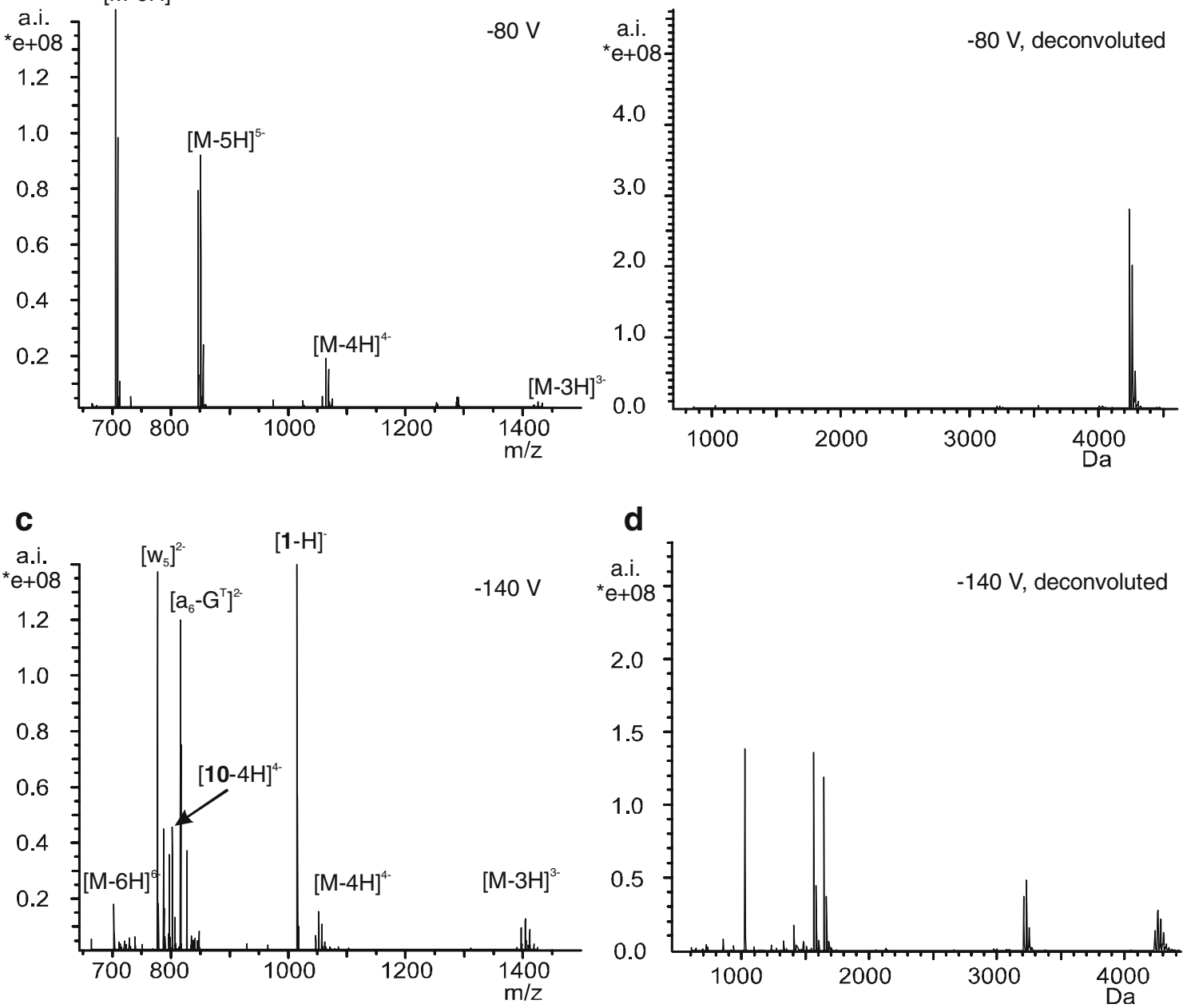

d

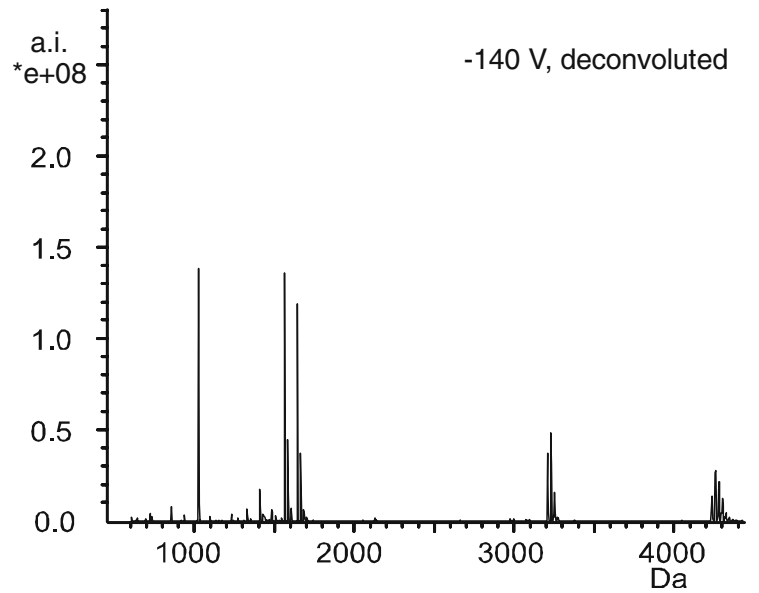

Fig. 9 a ESI mass spectrum of trioxacarin-DNA d(AATTAG ${ }^{\mathrm{T}}$ AAATT) $\mathbf{5 d}+$ trioxacarcin (2) adduct, capillary exit potential $-80 \mathrm{~V} ; \mathbf{b}$ Respective deconvoluted spectrum of trioxacarin-DNA 5d adduct; $\mathbf{c}$

ESI mass spectrum of trioxacarin-DNA d(AATTAG ${ }^{\mathrm{T}}$ AAATT) $\mathbf{5 d}+$ trioxacarcin (2) adduct, capillary exit potential $-140 \mathrm{~V}$; d Respective deconvoluted spectrum of trioxacarin-DNA $\mathbf{5 d}$ adduct 
cycle) whereas double strand formation was no longer detected after heating to $90{ }^{\circ} \mathrm{C}$. This leads to the conclusion that trioxacarcin A (2) addition and DNA degradation is accelerated with three neighboring guanines. The high tendency for adduct formation of trioxacarcin A (2) to dsDNA $6+7$ at $0{ }^{\circ} \mathrm{C}$ was indicated by an HPLC signal at $26.0 \mathrm{~min}$ nearly the size of the remaining oligomer 7 (Fig. 8a). Even after $24 \mathrm{~h}$ signals appeared at 30.8 and $31.6 \mathrm{~min}$ that were assigned to DNA 6 functionalized with two equivalents of trioxacarcin A (2). The amount of double substitution increased significantly within $72 \mathrm{~h}$ reaction time (Fig. 8b).

Further insight into the trioxacarcin A (2)-initiated substitution reaction and the DNA cleavage products were obtained by additional ESI MS experiments stepwise increasing the capillary-skimmer dissociation energy in the ion source [24-30]. Like increasing the temperature this also initiated fragmentation of alkylated DNA followed by strand cleavage. The adduct of trioxacarcin A (2) with oligomer $\mathbf{5 d}$ was unequivocally assigned by ESI MS with a low capillary exit voltage of $-80 \mathrm{~V}$ providing exclusively ions of the DNA-trioxacarcin complex 5d +2 (Fig. 9a): $\left([\mathrm{M}-3 \mathrm{H}]^{3-}\right.$,
$[\mathrm{M}-4 \mathrm{H}]^{4-},[\mathrm{M}-5 \mathrm{H}]^{5-}$, and $\left.[\mathrm{M}-6 \mathrm{H}]^{6-}\right)$. By applying capillary-skimmer dissociation by raising the capillary exit voltage to $-140 \mathrm{~V}$ the signals for the DNA-trioxacarcin A adduct were also found (Fig. 9c). Nevertheless, the adduct ions were less intense. One of the peaks with the highest intensity appears at $\mathrm{m} / \mathrm{z} 1026.37$; this is assigned to the single negatively charged ion of gutingimycin (1) comparable to the thermal cleavage product observed already by HPLC. Depurination is known to result in oligonucleotide strand scission $[19,20,27]$. Furthermore, it has been reported that collision-activated dissociation of negatively charged oligonucleotide ions starts with cleavage of a base followed by cleavage of the $3^{\prime} \mathrm{C}-\mathrm{O}$ bond of the sugar unit from which the base was lost [31]. In accordance, two ESI MS peaks were correlated to the doubly charged $\mathrm{w}_{5}$-fragment ion at $\mathrm{m} /$ $z 781.64$ (calculated 781.63) and the doubly charged $\left(\mathrm{a}_{6}-\mathrm{B}\right)$ type fragment ion at $\mathrm{m} / \mathrm{z} 821.66$ (calculated 821.64 ) of the oligonucleotide 5d. The accompanying smaller peaks to the right of $\mathrm{w}_{5}{ }^{2-}$ and $\left[\mathrm{a}_{6}-\mathrm{G}^{\mathrm{T}}\right]^{2-}$ were assigned to the corresponding $[\mathrm{M}+\mathrm{Na}-3 \mathrm{H}]^{2-}$ ions. These fragments might mechanistically be explained by the initiation of
Scheme 1 Proposed cleavage reaction of DNA-trioxacarcin A adduct<smiles>[R2]OP(=O)([O-])OCc1ccco1</smiles> 
strand cleavage at $\mathrm{C}^{\prime}$ ' leading to a furanyl unit at the $3^{\prime}$-end of d(AATTA) and a phosphoryl group at the $5^{\prime}$-end of the second fragment d(AAATT) [31]. An additional small peak $m / z 801.90[\mathbf{1 0}-4 \mathrm{H}]^{4-}$ can be assigned to the depurinated oligonucleotide 10 (Scheme 1, together with its sodium peak $\left.m / z 807.40[10+\mathrm{Na}-5 \mathrm{H}]^{4-}\right)$. Nevertheless, oligonucleotide 10 with a double bond between $\mathrm{C}^{\prime}$ and $\mathrm{C}^{\prime}$ (Scheme 1) has a calculated mass $[\mathbf{1 0}-4 \mathrm{H}]^{4-}$ of $m / z 801.89$ and $[\mathbf{1 0}+$ $\mathrm{Na}-5 \mathrm{H}]^{4-}$ of $m / z 807.38$ corresponding to the mass of the intermediate fragment. This assignment is clearly supported by the corresponding deconvoluted mass spectra (Figs. 9b and d).

The fragments observed for depurination and DNA strand scission of trioxacarcin-DNA adducts are in agreement with the results from Sheil reporting similar oligonucleotide fragmentation in ESI MS-MS experiments for various hedamycin-DNA adducts [19]. Based on the ESI MS fragments detected by cleavage of the trioxacarcinDNA adduct $(\mathbf{5 d}+\mathbf{2})$ the following products and intermediates for the fragmentation of the trioxacarcin-DNA adduct are proposed (Scheme 1): Depurination is generating gutingimycin (1) and the oligonucleotide with an abasic site 10 dissociating in fragment 8 with a furanyl unit at the 3'end ( $\mathrm{w}_{5}$-type fragment) and fragment 9 with a phosphorylated 5 -end ( $\mathrm{a}_{6}$-B-type fragment). The phosphoester 9 seems to be a perfect leaving group for generation of a furan.

The results described for the trioxacarcin-DNA $\mathbf{5 d}$ adduct were supported by the mass spectra of the trioxacarcin adducts with oligonucleotides $\mathbf{4 a - b}$ and $\mathbf{5 a - c}$. The signals assigned to adducts, abasic sites, fragments, and gutingimycin were also observed for these oligomer adducts. With low dissociation energy in the ion source (capillary exit potential $-80 \mathrm{~V}$ ) the adduct peak was obtained for the self complementary double strand $\mathbf{4 a}$ with guanine in the central position almost exclusively, whereas fragmentation already occurred in the case of oligomer $\mathbf{4 b}$ with the terminal guanine obtaining the gutingimycin signal as the most prominent. Trioxacarcin A adducts with oligonucleotides 5a-c always provided the strongest ESI MS signals for the adduct peaks using the lowest dissociation energy; nevertheless, the peak intensities corresponding to the other fragments varied. The trioxacarcin adducts with oligomers $\mathbf{5 a}$ and $\mathbf{5 d}$ were the most stable.

\section{Conclusions}

The formation of stable adducts of the natural product trioxacarcin A (2) with guanine-containing dsDNA was investigated by a combination of temperature-dependent UV and CD spectroscopy, high-performance liquid chromatography, and high-resolution mass spectrometry. Recognition and non-covalent binding of trioxacarcin A (2) to dsDNA seems to be a prerequisite for nucleophilic attack of the guanine to form a covalent complex. Preliminary evidence indicates that trioxacarcin A-DNA interaction has sequence specificity with greater reactivity observed for guanines $5^{\prime}$ to thymidines. Cleavage of the trioxacarcinDNA adducts can be initiated at higher temperatures or by applying capillary-skimmer dissociation by raising the capillary exit potential in mass spectrometry experiments leading to the formation of the bioactive secondary metabolite gutingimycin and DNA strand scission. As DNA cleavage products, a fragment with a furanyl unit at the 3 '-end was identified next to an oligonucleotide with a phosphorylated $5^{\prime}$-end.

Acknowledgements We are grateful for generous support of the Deutsche Forschungsgemeinschaft and of the Fonds der Chemischen Industrie.

Open Access This article is distributed under the terms of the Creative Commons Attribution Noncommercial License which permits any noncommercial use, distribution, and reproduction in any medium, provided the original author(s) and source are credited.

\section{References}

1. Tamaoki T, Shirahata K, Iida T, Tomita F (1981) J Antibiot 34:1524-1530

2. Tomita F, Tamaoki T, Morimoto M, Fujimoto K (1981) J Antibiot 34:1519-1524

3. Kayser O, Laatsch H, Maskey RP, Hansske F, Grün-Wollny I, Helmke E (2005) Trioxacarcins for use as antimicrobials, PCT Int. Appl. (01.09.2005), WO 2005080549; CA 143:225918

4. Shirahata K, Iida T, Hirayama N (1981) Tennen Yuki Kagobutsu Toronkai Koen Yoshishu 24:199-206

5. Maskey RP, Sevvana M, Usón I, Helmke E, Laatsch H. (2004) Angew Chem Int Ed 43:1281-1283

6. Maskey RP, Helmke E, Kayser O, Maier A, Fiebig HH, Busche A, Laatsch H (2004) J Antibiot 57:771-779

7. Gates KS (1999) DNA and aspects of molecular biology. Comprehensive natural product chemistry, vol 7. Elsevier, New York, pp 491-552

8. Hansen MR, Hurley LH (1996) Acc Chem Res 29:249-258

9. Sun D, Hansen M, Hurley L (1995) J Am Chem Soc 117:2430 2440

10. Maeda K, Takeuchi T, Nitta K, Yagishita K, Utahara R, Osato T, Ueda M, Kondo S, Okami Y, Umezawa H (1956) J Antibiot Ser A 9:75-81

11. Hara M, Yoshida M, Nakano H (1990) Biochemistry 29:10449-10455

12. Greenberg MM (1999) DNA and aspects of molecular biology. Comprehensive natural product chemistry, vol 7. Elsevier, New York, pp 371-425

13. Hurley LH (1996) Advances in DNA sequence specific agents, vol 2. JAI Press, Greenwich, CT

14. Hurley LH, Chaires JB (1993) Molecular aspects of anticancer drug-DNA interactions, vol 1. CRC Press, Boca Raton, FL

15. Chan KL, Sugiyama H, Saito I (1991) Tetrahedron Lett 32:7719-7722

16. Chan KL, Sugiyama H, Saito I, Hara M (1995) Phytochemistry 40:1373-1374

17. Prakash AS, Moore AC, Murray V, Matias C, McFadyen WD, Wickham G (1995) Chem-Biol Interact 95:17-28 
18. Murray V, Moore AC, Matias C, Wickham G (1995) Biochim Biophys Acta 1261:195-200

19. Iannitti P, Sheil MM, Wickham G (1997) J Am Chem Soc 119:1490-1491

20. Colgrave ML, Iannitto-Tito P, Wickham G, Sheil MM (2003) Aust J Chem 56:401-413

21. Hansen M, Hurley L (1995) J Am Chem Soc 117:2421-2429

22. Owen EA, Burley GA, Carver JA, Wickham G, Keniry MA (2002) 290:1602-1608

23. Polster J (1995) Reaktionskinetische Auswertung spektroskopischer Messdaten. Vieweg

24. Beck JL, Colgrave ML, Ralph SF, Sheil MM (2001) 20:6187
25. Huber CG, Oberacher H (2001) 20:310-343

26. Banoub JH, Newton RP, Esmans E, Ewing DF, Mackenzie G (2005) Chem Rev 105:1869-1915

27. Tietze LF, Krewer B, Frauendorf H, Major F Schuberth I (2006) Angew Chem Int Ed 45:6570-6574

28. Wickham G, Iannitti P, Boschenok J, Sheil MM (1995) FEBS Let 360:231-234

29. Beck JL, Colgrave ML, Ralph SF, Sheil MM (2001) Mass Spectrom Rev 20:61-87

30. Iannitti-Tito P, Weimann A, Wickham G, Sheil MM (2000) Analyst 125:627-634

31. McLuckey S, Habibi-Goudarzi S, (1993) J Am Chem Soc 115:12085-12095 